\title{
Tafilelt, the Neo Traditional Model of Ksour in Algeria: Assessment of the Multi-functionality of Urban Spaces
}

\author{
* PhD candidate SOUIDI MANEL 1 (iD) and Dr. BESTANDJI SIHAM 2 \\ 1 Laboratory of Mediterranean architecture (L.A.M), Institute of Architecture, Ferhat Abbas University, Setif 1, Algeria \\ 2 Laboratory city and health, Faculty of Architecture, Salah Boubnider University, Constantine 3, Algeria \\ E mail: sovidi31manel@gmail.com Email: sihambestandji@yahoo.fr
}

\begin{tabular}{l}
\hline A R T I C L E I N F O: \\
\hline Article history: \\
Received 06 May2018 \\
Accepted 25 June 2018 \\
Available online 12 October \\
2018 \\
\hline Keywords: \\
Tafilelt; \\
Multifunctional Urban \\
Spaces; \\
Neo Traditional Model; \\
Algerian Ksour. \\
\end{tabular}

This work is licensed under a Creative Commons Attribution - NonCommercial - NoDerivs 4.0. "CC-BY-NC-ND"

\begin{abstract}
A B S T R A C T
The new ksar of Tafilelt situated in Ghardaia in southern Algeria has attracted a lot of interest in scientific work, being a "neo traditional " urban model that reproduces the principles of composition and spatial organization of the ksour in the pentapolis of Ghardaia. This ksar embodies the adaptation between tradition and modernity: it refers to the local setting of the ksourien space production, contribute to the valorization of these ancient centers that date back to the XIth century.

In parallel to the work of thesis undertaken on " the neo traditional models of reference in Algeria for the new cities ", we ask the following questions according to the case of Tafilelt: Is this ksar really a model? Does it take the traditional model fully? Is this indeed a new city? In addition, speaking about the concept of multifunctionality. How to detect this integral reproduction in the urban spaces between the old and the new ksar?

This work will be an analytical reading of the spaces of this ksar according to the four concepts above, namely: the urban model of reference, the criteria of the new city, the criteria of the former ksour and the multi-use character of their spaces. We will try to apply the concept of multi-functionality on urban spaces in different scales to assess the multi-functionality of the ksar's spaces in a comparative approach between the old and the new ksour.
\end{abstract}

JOURNAL OF CONTEMPORARY URBAN AFFAIRS (2019), 3(2), 99-107.

Doi: https://doi.org/10.25034/ijcua.2018.4706

www.ijcua.com

Copyright (c) 2018 Journal Of Contemporary Urban Affairs. All rights reserved.

\section{Introduction}

The M'zab Valley in Algeria contains the most ancient urban centers in the world. The lbadite Muslims have built these fortified cities in the XI the century after running of the Rostumids from their original settlement in western Algeria (Marçais, 2004). They tried to get along with the hard climate in the Sahara and kept the ksar's houses for winter and the palm grove's houses for summer (Addad, 2012). The Mozabite built the ksour in the slope of the M'zab River to protect them from the floods. Each ksar has several entrances and surveillance towers, a mosque in the top and a marketplace (Souk). The UNESCO listed them in the world heritage since 1982 (Bouali-Messahel, 2011).

Since the 1990s, the Algerian government constructed new ksour beyond the old cores for many reasons (Gueliane, 2014):

- $\quad$ Treat the crisis of housing due to the

\footnotetext{
*Corresponding Author:

Institute of architecture, Setif 1 University, Algeria

E-mail address: souidi31manel@gmail.com
} 
increasing number of population.

- Improve the conditions of the framework built.

- $\quad$ Protect the cultural and natural values of the tangible and intangible heritage of the Valley.

- Have access to housing to the average class of Mozabite.

These ksour have a modern spatial organization, different from the local typology in adaptation with the specific conditions in Ghardaia. The introduction of the modern lifestyle recently participates in a standard composition in new housing and the new built up areas seems to be similar in the north or the south of Algeria, which leads to a lack of the local identity in the architectural and the urban scale.

The local foundations or the Mozabite themselves, fighting the loss of their model of reference, tried to build new cities that embodies the adaptation between tradition and modernity. It is the case of Tafilelt, it reproduces the traditional urban model of ksour, this study attempts to assess the multifuntionality of spaces in the new ksar according to the traditional model.

The figure 1 is illustrated the structure of the study about the urban models in the M'zab Valley and its importance to preserve the local heritage of this ancestral region.

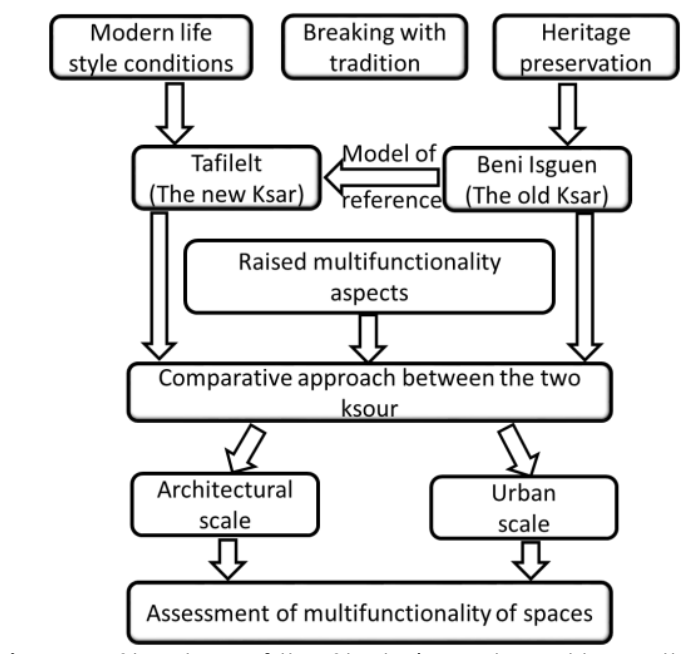

Figure 1. Structure of the Study (Developed by Author).

\section{The Neo traditional urban model in Ghardaia (Algeria)}

The first part of this study will attempt to present Beni Isguen as an urban model and Tafilelt as the modern adaptation of the fortified ancient city and will demonstrate that the former ksour were an urban model for the new ones.
Ghardaïa is a well-known region in Algeria, since Marc Cote and André Ravéreau (2003) up to present, its ksour have fascinated many architects and planners who wrote on the M'zab and were inspired in their achievements. The M'zab is a Muslim community of the very conservative Ibadite Sect. They always have a tendency to build and go live in a new ksar if the former is no longer enough for the new population. The descendants of the same tribe will then build the extension of their own city. This community has since long respected a "sustainable" lifestyle: wise recycling of household waste, use of local building materials and economical use of space. These criteria have advanced the work on the multifunctionality because density and multiuse space go together. The pentapolis contains five former ksour: El Atteuf built in 1012, Melika in 1350, Bounoura in 1046, Beni Isguen in 1347 and Ghardaia in 1048 (OPVM, 2017). The Algerian Government named the entire city after the last one. Guerrara built in 1631 and Berriane in 1679 are located in a few kilometers from the pentapolis (Chabi, 2008). The new ksour are Tinemmirine in 1992 and Tafilelt in 1997 fully completed and Thaounza (2004), which are the extension of Beni Isguen. The ksar of loumed built in 1995 belongs to Melika, Tineaâm built in 2008 was annexed to Bounoura. Finally, the ksar of Hamrayat built in 1996; Agherm Ouazem in 2007 and Ayrem Babaousmail in 2008 were located outside the Valley, belonging to the municipality of $\mathrm{El}$ Atteuf (Gueliane, 2015).

\subsection{The new ksar of Tafilelt}

Tafilelt is a project initiated in 1997 by the "Amidoul" Foundation, completed in 2011 on an area of 22.5 hectares, it contains with the 1050 housing units intended for Mozabite young couples, non-existing equipment in the former ksour: Gym, party hall, madrasa, cultural center and an ecological park (Gueliane, 2014). The mode of funding to build the houses is tripartite between the government, the foundation and the population. Therefore, Tafilelt is not a new town, the foundation didn' $t$ build it after a governmental decision and the laws, which regulate the new cities in Algeria, are not applied on this ksar. It is a purely an initiative from the foundation and the inhabitants. It is winner of the first prize of the "sustainable city" to the Conference of Parties (COP) 22 in Marrakech, Morocco in 2017.

This ksar is the extension of the ksar of Beni Isguen. One of the objectives of Amidoul 
Foundation in the project was the reinterpretation of the principles of urban planning in the local traditional housing (Addad, 2001b). The Intergenerational mix is also one of the element keys of the house design in Tafilelt, it can accommodate two to three generations (Addad, 2001a), we found after the distribution of the housing that the social mix is rather absent in this project (Gueliane, 2014).

\subsection{The old ksar of Beni Isguen}

Beni Isguen is the fourth fortified city in the M'zab Valley, known by its ancient mosque and its battlement of 2500 meter of length and three meter of higher including two principal surveillance towers: Boulila and Badahmane (OPVM, 2017). Its population is characterized by quite strict behavior rules and morals (Bovali-Messahel, 2011).

Like the other ksour, Beni Isguen contains an important marketplace where the commercial transactions were organized weekly; it was one of the rare opportunities where Mozabite allow to strangers to come into the city. The commercial streets contain the daily activities (hairdresser, greengrocer and grocery store). The houses are the most important component of the ksar, closely positioned to avoid the winds, built in gradient in the slope of the valley from the bottom until the top where the mosque is symbolically situated. It constitutes one of the last traditional ksourien model built by the mozabite.

In his book "A city fulfils its Valley: Ghardaia " Marc Cote (2002) said that the ksar is a module that is reproducible, organized in trilogy between the river, the ksar (the winter's settlement) and the Palme grove, which is the summer's settlement where the presence of the freshness mitigates the heat of the Sahara. Each module is independent and limited. The extension of each former ksar by a new and the description of Marc Cote confirm that the M'zab Valley has well and truly, a reference model reproducible for its new cities.

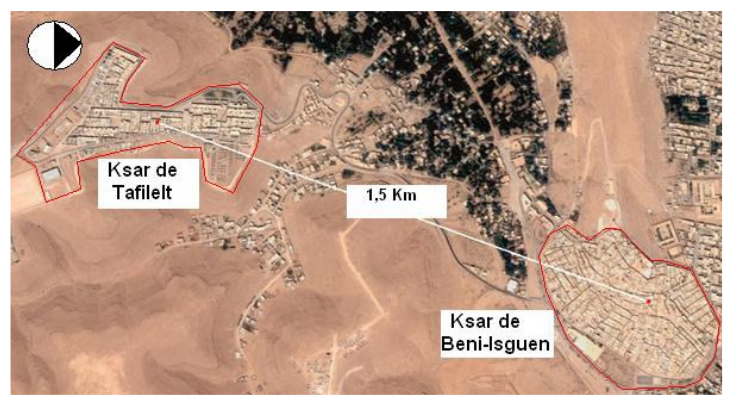

Figure 2: Situation of the two ksour with the distance between them. (Chabi, 2008)
According to Nora Gueliane, Tafilelt shares with Beni Isguen the same principles of planning to know: the compactness, templates, the prospect and the integration to the site. We are going in this work to take interest to the first principle of the "economical consumption of space" which logically generates the principle of multifunctionality of spaces. During the construction of Tafilelt, some urban problems have been resolved thanks to the traditional urban planning.

However, the constitution of the ksar of Tafilelt demonstrates that this new urban model aspires not only the protection, the enhancement and the sharing of the ksourien heritage; it also revisits these cultural values for an adaptation to a more modern life framework.
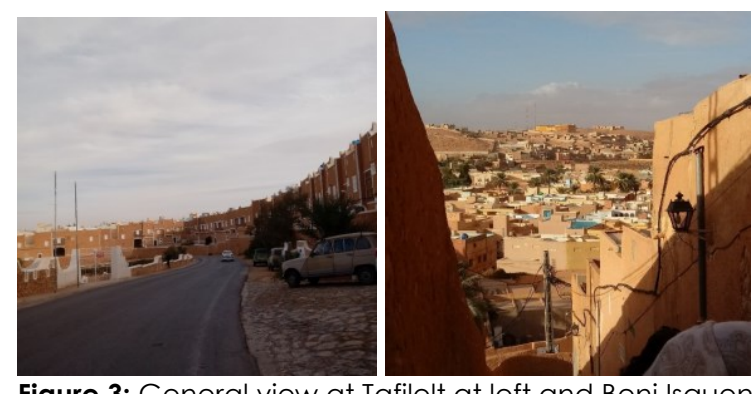

Figure 3: General view at Tafilelt at left and Beni Isguen at right (Author, 2017).

The table 1 attempts to compare between Beni Isguen and Tafilelt according to several elements both in architectural an urban scale. This information has been gathered during the visit to Ghardaia in December 2017 from documents provided by the architects who work in the OPVM (Office for the Promotion of the M'zab Valley, 2017). See table '1', in Appendix ' $A$ ', and this comparison provides us the following information:

- At an urban scale, Beni Isguen was a model of reference to Tafilelt in the site choice and implantation. The new settlement could protect the rare agricultural lands in the Valley from urban sprawl and because of the economic situation of its inhabitants, it has been yearly occupied and more appropriate for the modern lifestyle. It is also a way to guarantee a multifunctionality of land use. The urban landscape was respected because it refers to the model of reference and the ethics of Mozabite, the homogeneous height and colors of facades reflect equality between families. 
- $\quad$ The main streets in Tafilelt are wider than in Beni Isguen. In fact, each household has a car in the ksar, the large dimensions of the streets guarantee a mechanical accessibility.

- $\quad$ There are many places in Tafilelt dispersed between the neighborhoods unlike Beni Isguen where a main place was the public space for all users.

- At an architectural scale, and thanks to the social cohesion between the Mozabite, Beni Isguen still a model of reference to Tafilelt with an adaptation to the modern lifestyle, the differences between Beni Isguen's houses and Tafilelt's houses are minimal (the existence of a garage and a yard in the new houses).

- The neotraditional house is more spacious and occupies the whole first floor; it also contains a laundry room in the terrace.

At the end, we may conclude that Tafilelt is a neo traditional urban model of ksour in Algeria even if it is not a new town; this ksar could preserve the traditional model in either the architectural or the urban dimensions with a successful adaptation of the current life framework. It reproduces symbolically some elements in order to maintain the heritage conservation. This project has broken with the current Algerian policy of standard housing. Therefore, one of the ancient concepts that Tafilelt maintains is the diversity of its activities in a limited space. Inside the ksar, the inhabitants tried to project all their needs in order to create an urban diversity and a functional mix.

\section{Assessment of multi-functionality between the ksour of Ghardaia}

The second part of the study approaches the concept of multi-functionality in general and in the two ksour of Ghardaia in particular in order to assess this concept between the traditional and the neo traditional models.

Multifuntionality as a concept has several roots (Ghafouri, 2016): some authors consider it as an old architectural concept in urban areas by relating it to the ancient Greek or medieval constructions (Zeidler, 1985), others consider it as the ability of spaces to fulfill more than one function simultaneously (Grant, 2010).

The concept of the mixed and compact town appears with the "smart growth" in the United States at the beginning of the 1990s, it emphasis on diversity of use and urban functions with the creation of a favorable environment for pedestrians. This concept had an echo in Europe and with a Dutch then a German evolution that it becomes the "urban multifunctional land use MLU" or the concept of multifunctional use of urban space. It was inspired by the agriculture field where it was largely applied to increase the rural production (Dufour et al., 2007). It encourages a model of a compact city with diverse functions especially with a synergy between the proposed functions (De Groot, 2004). Recently, MLU inspires urbanists in sustainable urban planning because it breaks with the zoning design of the modern style, cause of the urban sprawl (Jacobs, 1961). This concept has also other benefits: reduces the need for new constructions, increases the density in urban areas and leads to more cities that are vital economically and socially (Batty et al., 2003).

The assessment of MLU in urban spaces uses the aspects below (Ghafouri, 2016):

- Space: which is the most important topic; the study area is a place, a street, a building, a house, a room, a terrace or even a sidewalk. It could be open or closed, public or private.

- Time: in architecture, an activity occurs in a time framework (Ghafouri, 2016): during the day or the night, during a week, a month, a season or all over the year.

- $\quad$ Function: a space could have various functions; we can distinguish different types of activities that occur in a space: necessary and functional, optional or social activities (Gehl, $2011)$.

- $\quad$ Users: the people that are occupying the space could be recognized according to their gender (men or women), or age (children, young or elderly person).

- Scale: Basically, there are three scales in urban studies: architectural scale (the building analysis), neighborhood scale and urban scale (at the level of a town or city).

- Legal status: it refers to who owns the concerned space; this could give us an idea about the importance, accessibility and flow of a space.

In fact, there is a close relationship between time, space and function to characterize the multifunctionality. For this reason, we will consider those three aspects in addition to users to assess MLU in the two cases. We already divide the study according to the scale and will mention, but not consider the legal status.

\subsection{Multifunctionality in Beni Isguen}

Like other ancient cores, Beni Isguen is compact with a mixed uses. This returns to the climatic conditions of Ghardaia in one hand and the principle of land economy in another 
hand. The table 2 studies the aspects of multifunctionality in the old ksar in the most important and significant spaces. We will consider each type of space according to the degree of its multi-use:

- A functional space is considered with the sign (0) because it does not contribute to the multifunctionality of the ksar. However, it has a function, few users and one occupation time at a long period (week, month or season).

- A multifunctional space is considered with the sign $(+)$ because it has more than one function, attracts different types of users who occupy it in different time a year.

- $\quad$ A mono functional space is considered with the sign (-), this kind of spaces have only one function intended for one kind of users and rarely occupied.

The study will not treat in an exhaustive manner the gradation of each degree of

multifunctionality for the amenities of the presentation. The next table represents the different ksourien spaces with a description of their aspects. See table '2', Appendix 'A'.

\subsection{Multifunctionality in Tafilelt}

Tafilelt follows an orthogonal tracing, hierarchical wider ways with compactness due to the land economy. New equipment appears in the new ksar and the mosque always keeps the summit of the ksar.

The table 3 resumes the same aspects with the same considerations mentioned above in Tafilelt architectural and urban spaces. See table ' 3 ', in Appendix ' $A$ '.

\subsection{Results}

This study shows that the logic behind the construction of the traditional cores is implied. A ksar is always a reflection of deep social, cultural and religious values. The intention to separate between the architectural and the urban scale was hard in this case because the traditional design thinks simultaneously the micro and the macro scale. It is a complex thought that users practice to build their settlement long time ago, different from the linear planning of towns nowadays.

Tafilelt respects integrally the traditional model and reflects perfectly the multifunctionality of its spaces mostly in the architectural scale using the same spaces: patio, terrace, reception rooms, and kitchen with the same traditional concept.

The neo traditional ksar has indeed mono functional spaces like the cultural center and the madrasa who were included in the mosque in ancient times. The yard, the garage and the laundry room in the house have one function, previously, their activities were practiced in the patio.

Fortunately, in urban scale, Tafilelt was a multifunctional neo traditional model:

- The annual occupation densifies the ksar with multiuses and protects the palm grove from urban sprawl and consumption of agricultural lands.

- The reuse of symbolic elements like the surveillance towers also increase the multifunctional land use after their occasional use.

- The introduction of new equipment helps reach the intense land uses in a limited space (inside the ksar's limits) and an adaptation of the modern life (the ecological park, the gym for young and children).

\section{Conclusions}

This work tries to respond to the questions formulated previously, namely if the former ksour were urban models for the new and confirms the hypothesis, that Tafilelt is really a neo traditional model by its modern reinterpretation of the ksourien space.

In the first part of the work, we have demonstrated that Tafilelt is not a new city according to the Algerian regulations, but it takes Beni Isguen as an urban model of reference thanks to the social cohesion between the Mozabite who still respect their social and cultural heritage references. We have also been able to raise the criteria of multifunctionality of a space in the old centers.

In the second part, we checked the multifunctionality of spaces in the old and the new ksar in a comparative approach according to the raised and applied criteria of MLU in both architectural and urban scale.

These results showed that a neo traditional model could preserve the ancient advantages of the traditional model (the site choice, the implantation, the spatial organization in the traditional house, marketplaces and stores). It also develops some modern criteria and integrates them with the traditional advantages (the yard and garage in the house and the gym, cultural center and the ecological park, which is a leisure area and an opportunity to increase the agricultural land in addition to the palm grove) 


\section{Acknowledgments}

I would like to express my sincere thanks to Dr. BESTANDJI Siham, my Ph.D director for her time, help and support to accomplish this article and to Dr. Hourakhsh Ahmad Nia, chairman of the ICCAUA2018 conference, for all his help and understanding. This research did not receive any specific grant from funding agencies in the public, commercial, or non-forprofit sectors.

\section{Conflict of interests}

The authors declare no conflict of interest.

\section{References}

Addad, M.C. (2011a). Les anciens et les nouveaux ksour: étude comparative. Cas du M'zab [Old and new ksour: comparative study. Case of M'zab], Courrier du Savoir, 16, 77-87, retrieved from:https://www.academia.edu/28667619/L ES_ANCIENS_ET_NOUVEAUX_KSOUR_ETUDE_C OMPARATIVE._CAS_DU_MZAB

Addad, M.C. (2011b). Les éco-ksour au M'zab: Tentative de faire la ville en référence au développement durable [Eco-ksour in M'zab: Attempt to make the city in reference to sustainable development], (conference paper), Biskra Architecture and Sustainability Conference, department of architecture, Biskra, Algeria. Retrieved from https://www.academia.edu/28536437/Les_\% C3\%A9co-

ksour_au_M_zab_Tentative_de_faire_la_ville_ en_r\%C3\%A9f\%C3\%A9rence_au_d\%C3\%A9ve loppement_durable

Addad M. C. \& Redjem A. (2012). Production de l'habitat dans les nouveaux ksour, symbiose entre intervention de l'Etat et action Communautaire : cas du Ksar Tafilelt dans la vallée du M'zab [Habitat production in the new ksour, symbiosis between state intervention and Community action: the case of Ksar Tafilelt in the M'zab valley]. Perspectives \& Sociétés, 3(2), 124-148. Retrieved from

http://www.academia.edu/28517226/Produc tion_de_Ihabitat_dans_les_nouveaux_ksour_s ymbiose_entre_intervention

Batty, M., Besussi, E., Maat, K., \& Harts, J. (2003). Representing multifunctional cities: density and diversity in space and time [Working / discussion paper]. Retrieved from http://discovery.ucl.ac.uk/215/

Bouali-Messahel, M. (2011). Tafilelt, a community project to preserve the M'Zab Valley, [conference paper], Toulouse, France. Retrieved https://www.google.fr/url? sa=t\&rct=j\&q=\&esr $c=s \&$ source $=$ web \& $c d=1 \& c a d=r j a \& u a c t=8 \& v$ ed=2ahUKEwiAyY2AoNHeAhUSLBoKHXLPDw8 QFjAAegQICRAC\&url=https\%3A\%2F\%2Fwww. enhr.net\%2Fdocuments\%2F201 1\%2520France \%2FWS09\%2FPaper-Mounia\%2520BOUALIMESSAHEL-

WS09.pdf\&usg=AOVVaw1Gg5GAIMd0ORL5gT 9uEk3d

Brandt, J., \& Vejre, H. (2004). Multifunctional landscapes - motives, concepts and perceptions. In J. Brandt, \& H. Vejre (Eds.), Multifunctional Landscapes: Volume 1 Theory, Values and History, 3-32. Southhampton, UK: WIT Press. Advances in Ecological Sciences, Vol. $1 . \quad$ Retrieved from https://forskning.ruc.dk/en/publications/multif unctional-landscapes-motives-concepts-andperceptions

Chabi. M, Dahli. M. (2008). Le patrimoine: Un référent pour le renouvellement urbain? Cas des ksour du M'Zab [Heritage: A referent for urban renewal? Case of ksour of M'Zab], (Conference paper), Department of architecture, Mouloud Mammeri University, Tizi-Ouzou, Algeria, 9. Retrieved from https://www.google.fr/url? sa=t\&rct=j\&q=\&esr $c=s \&$ source $=$ web \& $c d=1 \& c a d=r j a \& u a c t=8 \& v$ ed=2ahUKEwiN-

rOxodHeAhWlyoUKHWpyB_kQFjAAegQICRAC \&url=http\%3A\%2F\%2Fwww.asrdlf2013.org\%2FI MG\%2Fpdf\%2FC_-_CHABI_-_DAHLI_-

_Le_patrimoine_Un_referent_pour_le_renouve llement_urbain.pdf\&usg=AOvVaw2AOWfO7kL kKv3F_nMRnkBO

Côte, M. (2002). Une ville remplit sa vallée: Ghardaiia [A city fills its valley: Ghardaia] (Note). Méditerranée, 99(3), 107-110. https://doi.org/10.3406/medit.2002.3270

De Groot, H. L. F., Vreeker, R., \& Verhoef, E. (2004). Urban Multifunctional Land Use: Theoretical and Empirical Insights on Economies of Scale, Scope and Diversity. Built Environment, 30, 289-307. https://doi.org/10.2148/benv.30.4.289.57157

Dufour, A., Mauz, I., Rémy, J., Bernard, C., Dobremez, L., Havet, A. \& Tchakérian, E. (2007). Multifunctionality in Agriculture and its Agents: Regional Comparisons. Sociologia Ruralis, $\quad 47$, 316-342. https://doi.org/10.1111/j.14679523.2007.00444. $x$

Gehl, J. (2011). Life between Buildings: Using Public Space (sixth Ed.). Washington DC, USA: Island Press. Retrieved from https://trove.nla.gov.au/work/9589146?.q\&ver sionld=31583026 
Ghafouri, A. (2016). La forme urbaine durable: Multifonctionnalité et adaptation. Redéfinir les espaces urbains en tant que zones partagées multifonctionnelles [The sustainable urban form: Multifunctionality and adaptation. Redefining urban spaces as multifunctional shared areas], (PhD. Thesis), Faculty of geography, Strasbourg University, France. Retrieved from http://www.theses.fr/2016STRAH004

Grant, L. (2010). Multi-Functional urban green infrastructure: The chartered institution of water and environment management. Retrieved from https://www.ciwem.org/policy-reports/multifunctional-urban-green-infrastructure

Gueliane, N. (2014). Une réinterprétation sociale et spatiale d'un patrimoine millénaire, le nouveau ksar Tafilelt dans la vallée du M'zab [A social and spatial reinterpretation of an ancient heritage, the new ksar Tafilelt in the M'zab Valley], http://fr.calameo.com/read/004001565176fO $02 f 8 f 76$.

Gueliane, N. (2015). Les nouveaux ksour de la vallée du M'zab: Le produit d'une dynamique sociale [The new ksour of the M'zab valley: the product of a social dynamic], (seminar paper), International Seminar : Living in Algeria: International Experiences and Comparisons), Batna, Algeria. Retrieved from https://www.google.fr/url? sa=t\&rct=j\&q=\&esr $c=s \&$ source $=$ web\& $c d=1 \& c a d=r j a$ \& uact $=8 \& \mathrm{v}$ ed=2ahUKEwj44LPIpNHeAhUJ2BoKHXe3BhoQ FjAAegQICBAC\&url=http\%3A\%2F\%2Fcrh.ehes s.fr\%2Fdocannexe\%2Ffile\%2F4529\%2Fcolloque _batna_repaired.pdf\&usg=AOVVaw10cOB8A yv69Z6_81ehBZXG

Hansen, R., Olafsson, A. S., van der Jagt, A. P. N., Rall, E., \& Pauleit, S. (2017). Planning multifunctional green infrastructure for compact cities: What is the state of practice? Ecological Indicators. https://doi.org/10.1016/j.ecolind.2017.09.042

Jacobs, J. (1992). The Death and Life of Great American Cities (Reissue edition). New York, USA: Vintage. Retrieved from https://edwardbetts.com/monograph/The_D eath_and_Life_of_Great_American_Cities

Marçais, G. (2004). Villes et campagnes d'Algérie [Cities and countryside of Algeria]. Paris, France: Editions Tell, 150p. Retrieved from https://www.abebooks.fr/rechercherlivre/titre/villes-et-campagnes-d\%27algerie/

Meyer, B., \& Degorski, M. (2007). Integration of multifunctional goals into land use - The planning perspective. Multifunctional Land
Use: Meeting Future Demands for Landscape Goods and Services, 153-166. https://doi.org/10.1007/978-3-540-36763-5_10

Office of Promotion of the M'zab Valley (OPVM), Ghardaia, (Dec 2017). Brochures: Presentation of the wilaya of Ghradaia, the traditional habitat, the ancient ksour, the customs of construction in M'zab].

Ravéreau, A., Roche, M., \& Fathy, H. (2003). Le M'Zab, une leçon d'architecture [The M'Zab, an architectural lesson]. Arles, France: Actes Sud. Retrieved from https://www.actessud.fr/catalogue/architecture-eturbanisme/le-mzab-une-lecon-darchitecture

Vreeker, R., de Groot, H. L. F., \& Verhoef, E. (2004). Urban Multifunctional Land Use: Theoretical and Empirical Insights on Economies of Scale, Scope and Diversity. Built Environment, 30, 289-307. https://doi.org/10.2148/benv.30.4.289.57157

Wiggering, H., Dalchowa, C., Glemnitz, M., Helming, K., Muller, K., Schultz, A., Stachowa, U. \& Zander, P. (2006). Indicators for multifunctional land use linking socioeconomic requirements with landscape potentials. In Ecological Indicators. Elsevier, 6(1), 238-249. https://doi.org/10.1016/j.ecolind.2005.08.014

Zeidler, E. H. (1985). Multi-use architecture in the urban context (Second Edition). New York, USA: Van Nostrand Reinhold. https://www.abebooks.com/Multi-UseArchitecture-Urban-Context-EberhardZeidler/1304127972/bd 


\section{Appendix 'A': Tables}

Table 1. A comparison between the old and the new ksar of the Valley (Developed by the author).

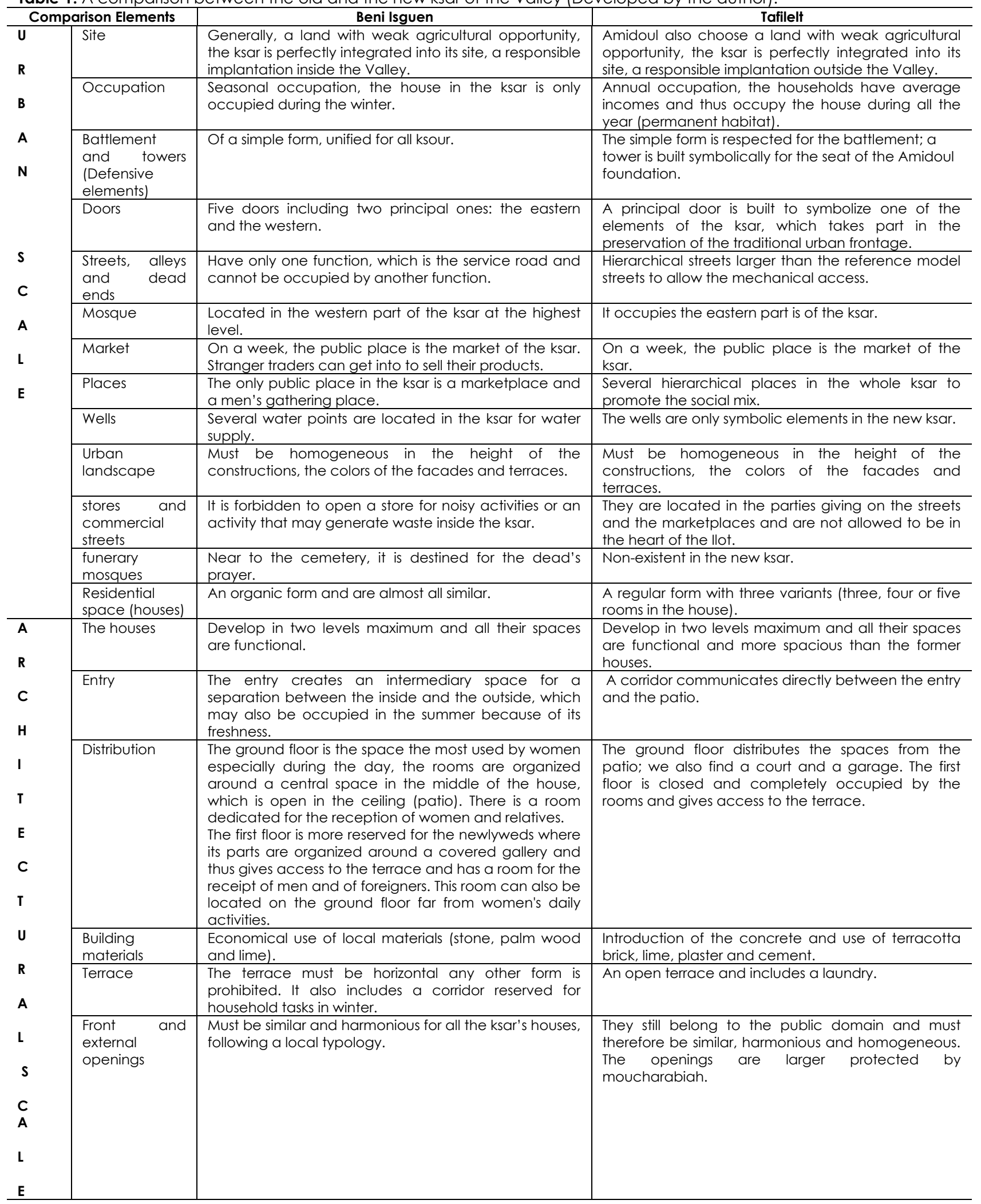




\begin{tabular}{|c|c|c|c|c|c|}
\hline Scale & Spaces & Time & Functions & Users & $\begin{array}{c}\text { Considerati } \\
\text { on }\end{array}$ \\
\hline \multirow{2}{*}{$\begin{array}{l}\mathbf{U} \\
\mathbf{R} \\
\mathbf{B} \\
\mathbf{A} \\
\mathbf{N}\end{array}$} & Ksar & $\begin{array}{l}\text { Seasonal occupation } \\
\text { (winter) }\end{array}$ & $\begin{array}{l}\text { Necessary/Optional/ } \\
\text { Social functions }\end{array}$ & All types of users & $(+)$ \\
\hline & $\begin{array}{c}\text { Battlement and } \\
\text { towers (Defensive } \\
\text { elements) } \\
\end{array}$ & $\begin{array}{l}\text { Occasional occupation } \\
\text { (of surveillance) }\end{array}$ & Necessary function & $\begin{array}{c}\text { Young men who } \\
\text { volunteer to survey the } \\
\text { ksar }\end{array}$ & $(-)$ \\
\hline \multirow{7}{*}{$\begin{array}{l}S \\
C \\
A \\
L \\
E\end{array}$} & $\begin{array}{l}\text { Streets, alleys and } \\
\text { dead ends }\end{array}$ & $\begin{array}{c}\text { All day except afternoon } \\
\text { while the inhabitants of the } \\
\text { ksar stay at home }\end{array}$ & Necessary function & $\begin{array}{l}\text { All users/ } \\
\text { Women use often the } \\
\text { alleys and dead ends } \\
\text { more than main streets }\end{array}$ & $(-)$ \\
\hline & Mosque & Permanent occupation & $\begin{array}{l}\text { Necessary/Optional/ } \\
\text { Social functions }\end{array}$ & $\begin{array}{c}\text { Generally men at } \\
\text { different ages and } \\
\text { children }\end{array}$ & $1+1$ \\
\hline & Market & Weekly occupation & $\begin{array}{l}\text { Necessary/Optional/ } \\
\text { Social functions }\end{array}$ & $\begin{array}{c}\text { Generally men at } \\
\text { different ages and } \\
\text { children }\end{array}$ & $1+1$ \\
\hline & Places & Occasional occupation & $\begin{array}{l}\text { Optional/ Social } \\
\text { functions }\end{array}$ & Men/children & $1+1$ \\
\hline & $\begin{array}{c}\text { stores and } \\
\text { commercial streets }\end{array}$ & Permanent occupation & $\begin{array}{l}\text { Optional/ Social } \\
\text { functions }\end{array}$ & All users & (0) \\
\hline & funerary mosques & Occasional occupation & Social function & Men & $(-)$ \\
\hline & $\begin{array}{l}\text { Residential space } \\
\text { (houses) }\end{array}$ & Permanent occupation & $\begin{array}{l}\text { Necessary/Optional/ } \\
\text { Social functions }\end{array}$ & All users & $(+)$ \\
\hline \multirow{5}{*}{$\begin{array}{l}\text { Archite } \\
\text { ctural } \\
\text { Scale }\end{array}$} & Rooms & At night & Optional function & All users & (0) \\
\hline & Entry & Occasional occupation & Optional function & $\begin{array}{l}\text { Women at different ages, } \\
\text { men use it as a passage }\end{array}$ & (0) \\
\hline & Patio & Daily occupation & $\begin{array}{l}\text { Necessary/Optional/ } \\
\text { Social functions }\end{array}$ & Women generally & $(+)$ \\
\hline & Terrace & Permanent occupation & $\begin{array}{l}\text { Necessary/Optional/ } \\
\text { Social functions }\end{array}$ & All users & $1+1$ \\
\hline & Kitchen & Daily occupation & Necessary function & Women only & (0) \\
\hline
\end{tabular}

\begin{tabular}{|c|c|c|c|c|c|}
\hline Scale & Spaces & Time & Functions & Users & $\begin{array}{l}\text { Considerat } \\
\text { ion }\end{array}$ \\
\hline \multirow{3}{*}{$\begin{array}{l}\text { U } \\
\mathbf{R} \\
\mathbf{B} \\
\mathbf{A} \\
\mathbf{N}\end{array}$} & Ksar & Annual occupation & $\begin{array}{l}\text { Necessary/Optional/ } \\
\text { Social functions }\end{array}$ & All types of users & $(+)$ \\
\hline & $\begin{array}{c}\text { Battlement and towers } \\
\text { (The seat of the foundation) }\end{array}$ & Daily occupation & $\begin{array}{l}\text { Symbolic/ optional } \\
\text { functions }\end{array}$ & The foundation members & $(+)$ \\
\hline & Streets, alleys and dead ends & $\begin{array}{l}\text { Permanent } \\
\text { occupation }\end{array}$ & $\begin{array}{l}\text { Necessary/Optional/ } \\
\text { Social functions }\end{array}$ & All types of users & $(+)$ \\
\hline \multirow{9}{*}{$\begin{array}{l}S \\
C \\
A \\
L \\
E\end{array}$} & Mosque & $\begin{array}{l}\text { Permanent } \\
\text { occupation }\end{array}$ & $\begin{array}{l}\text { Necessary/Optional/ } \\
\text { Social functions }\end{array}$ & $\begin{array}{c}\text { Generally men at different } \\
\text { ages and children }\end{array}$ & $(+)$ \\
\hline & Market & Weekly occupation & Necessary function & $\begin{array}{c}\text { Generally men at different } \\
\text { ages and children }\end{array}$ & (0) \\
\hline & Places & Daily occupation & $\begin{array}{c}\text { Optional/ } \\
\text { Social functions }\end{array}$ & Men/children & $(+)$ \\
\hline & stores and commercial streets & Daily occupation & $\begin{array}{l}\text { Necessary/Optional/ } \\
\text { Social functions }\end{array}$ & All types of users & $(+)$ \\
\hline & Residential space (houses) & $\begin{array}{l}\text { Permanent } \\
\text { occupation }\end{array}$ & $\begin{array}{l}\text { Necessary/Optional/ } \\
\text { Social functions }\end{array}$ & All types of users & $(+)$ \\
\hline & Ecological park & $\begin{array}{l}\text { Occasional } \\
\text { occupation }\end{array}$ & $\begin{array}{c}\text { Optional/ } \\
\text { Social functions }\end{array}$ & All types of users & $(+)$ \\
\hline & Party hall & $\begin{array}{l}\text { Occasional } \\
\text { occupation }\end{array}$ & $\begin{array}{c}\text { Optional/ } \\
\text { Social functions }\end{array}$ & All types of users & (0) \\
\hline & Gym & $\begin{array}{l}\text { Occasional } \\
\text { occupation }\end{array}$ & $\begin{array}{c}\text { Optional/ } \\
\text { Social functions }\end{array}$ & Young men and children & (0) \\
\hline & Cultural center & $\begin{array}{l}\text { Occasional } \\
\text { occupation }\end{array}$ & $\begin{array}{c}\text { Optional/ } \\
\text { Social functions }\end{array}$ & $\begin{array}{c}\text { Men at different ages and } \\
\text { children }\end{array}$ & (0) \\
\hline \multirow{7}{*}{$\begin{array}{l}\text { Archite } \\
\text { ctural }\end{array}$} & Rooms & At night & Optional function & All users & (0) \\
\hline & Entry & $\begin{array}{l}\text { Occasional } \\
\text { occupation }\end{array}$ & Optional function & $\begin{array}{c}\text { Men and women use it as a } \\
\text { passage }\end{array}$ & (0) \\
\hline & Patio & Daily occupation & $\begin{array}{l}\text { Necessary/Optional/ } \\
\text { Social functions }\end{array}$ & Women generally & $(+)$ \\
\hline & Terrace & $\begin{array}{l}\text { Permanent } \\
\text { occupation }\end{array}$ & $\begin{array}{l}\text { Necessary/Optional/ } \\
\text { Social functions }\end{array}$ & All users & $(+)$ \\
\hline & Kitchen & Daily occupation & Necessary function & Women only & (0) \\
\hline & Garage & $\begin{array}{l}\text { Occasional } \\
\text { occupation }\end{array}$ & Optional function & All users & (0) \\
\hline & Yard & $\begin{array}{c}\text { Seasonal } \\
\text { occupation }\end{array}$ & Optional function & All users & $(-)$ \\
\hline
\end{tabular}

